\title{
Protecting Research Confidentiality via the Wigmore Criteria: Some Implications of Parent and Bruckert $v$ The Queen and Luka Rocco Magnotta
}

Ted Palys and David MacAlister*

\begin{abstract}
There have been two significant legal challenges to research confidentiality in Canada. The first occurred because of a Coroner's subpoena, with the researcher invoking the Wigmore criteria and winning a researcher-participant privilege. A second case saw two University of Ottawa researchers served with a search warrant for the tape and transcript of an interview they had conducted years earlier with an individual subsequently accused of murder. The researchers defended research confidentiality in Quebec Superior Court, winning a qualified researcher-participant privilege in the process. This article discusses implications of the court's decision for researchers, research ethics boards, and universities for the future defence of research confidences. All have a role to play in designing research that anticipates the court's evidentiary requirements when a claim of privilege is invoked to help ensure future jurisprudence is as favourable to research participants and as respectful of academic freedom as possible.
\end{abstract}

Keywords: wigmore, research ethics, confidentiality, privilege, ethics and law

\section{Résumé}

Le Canada a connu deux importantes contestations judiciaires à la confidentialité de la recherche. La première a surgi d'une assignation d'un coroner, où le chercheur a invoqué le critère de Wigmore et défendu avec succès le privilège de la relation chercheur-participant. Dans la seconde, deux chercheures de l'Université d'Ottawa ont reçu un mandat de saisie des enregistrements et transcriptions d'une entrevue menée des années auparavant auprès d'une personne ultérieurement accusée de meurtre. Les chercheures ont défendu la confidentialité de leur recherche devant la Cour supérieure du Québec, remportant, lors de ce processus, une immunité relative de chercheur-participant. Cet article examine les répercussions de la décision de la Cour pour les chercheurs, les comités d'éthique et les universités dans les futurs cas de confidentialité de recherche. En effet, tous ont un rôle à jouer dans la conception de projets de recherche anticipant les exigences en matière de preuve des tribunaux en cas de revendication

The authors thank the editor and two anonymous reviewers for their thoughtful comments on an earlier draft.

Canadian Journal of Law and Society / Revue Canadienne Droit et Société, 2016,

Volume 31, no. 3, pp. 473-493. doi:10.1017/cls.2016.27 
de privilège, ceci afin d'assurer une jurisprudence à la fois favorable aux participants de recherche et respectueuse de la liberté académique.

Mots clés : wigmore, éthique de la recherche, confidentialité, privilège, éthique et droit

\section{A First Legal Challenge to Research Confidentiality}

The previously theoretical threat of authorities in Canada using legal mechanisms to seek disclosures of confidential research information became real in 1994 . It arose in the context of an inquest the Vancouver Coroner was conducting into "the death of the unknown female." He initiated the inquest because of an article that had appeared in the Vancouver Province newspaper describing the assisted suicide of an unnamed woman with AIDS. ${ }^{1}$ The article described how a sympathetic doctor had "prescribed enough Seconal to kill half of BC," and how a friend of the woman oversaw and assisted in her death at her request.

The inquest marked the first time in Canada a researcher was subpoenaed and asked to divulge information the researcher had promised to keep confidential. The researcher was Russel Ogden, a former graduate student in Criminology at Simon Fraser University whose Master's thesis included interviews with individuals who had participated in assisted suicides of persons with HIV/AIDS. Given the lack of both a body and the name of the deceased, the Coroner wondered whether Ogden might know the names of the two individuals who assisted in the death of the unknown female, and subpoenaed him to ask that question under oath. Ultimately, the case would raise important questions about the relationship between ethics and law, and of the ethical obligations that surround the relationship between research participants, researchers, and university administrations. ${ }^{2}$

Despite being effectively abandoned by his university, ${ }^{3}$ Ogden attended the inquest and responded to the Coroner's questions regarding his general research findings and knowledge of the literature. However, he refused to name either of the persons involved in the death on the basis of his ethical promise of confidentiality, at which point he was threatened with a charge of contempt. In the absence of any statute-based privilege in Canada for the researcher-participant relationship, ${ }^{4}$ Ogden argued that a public interest privilege for the researcherparticipant relationship should be recognized in this instance. He did so by invoking the Wigmore criteria, a common law test devised by former Northwestern University Dean of Law John Henry Wigmore more than a century ago that the

Lyn Cockburn, “An Act of Courage," The Vancouver Province, May 12, 1991, 29.

See Ted Palys and John Lowman, Protecting Research Confidentiality: What Happens When Law and Ethics Collide (Toronto: Lorimer, 2014).

3 John Lowman and Ted Palys, "Ethics and Institutional Conflict of Interest: The Research Confidentiality Controversy at Simon Fraser University," Sociological Practice: A Journal of Clinical and Applied Sociology 2, no. 4 (2000): 245-55. Years later, the university would acknowledge its mistake and apologize; see Palys and Lowman, ibid.

4 The one exception here is the privilege afforded researchers at Statistics Canada via the Statistics Act. RSC 1985, c S-19. 
Supreme Court of Canada has adopted for evaluating claims of privilege on a case-by-case basis. ${ }^{5}$

Although Ogden's claim for privilege was successful, the Coroner's judgment was not particularly informative as to the persuasiveness of specific arguments, finishing only with the statement that,

\begin{abstract}
Mr. Crossin ${ }^{6}$ called witnesses who testified to the public good that has flowed from Mr. Ogden's publication. His witnesses detailed the steps required to ensure confidentiality, the necessity of this confidentiality and the contribution this document has made to the society as a whole and to persons with AIDS in particular. I am convinced after listening to the testimony and the arguments of Mr. Crossin that, in fact, Mr. Ogden should not be compelled to answer questions that would breach his promise of confidentiality. ${ }^{7}$
\end{abstract}

The specific arguments and their merit would be considered later in a formal legal opinion by legal scholars Michael Jackson and Marilyn MacCrimmon, ${ }^{8}$ who concluded the ruling would have withstood judicial review.

\title{
A Second Legal Challenge
}

The May 2012 murder of Lin Jun, a student from China attending Concordia University, was a particularly gruesome one. The offender in the case was alleged to have performed various indignities upon the victim's body. Information gathered during the investigation quickly led police to suspect Luka Magnotta as the offender responsible for the crime.

Upon hearing this, Adam McLeod contacted Montreal police to inform them he had conducted an interview with Magnotta, under the pseudonym "Jimmy," that addressed wide-ranging aspects of Magnotta's personal and professional life. The interview occurred when McLeod was a research assistant for University of Ottawa Professors Chris Bruckert and Colette Parent for their 2007 study of sex workers and their clients. His decision to contact police occurred without the knowledge of Professors Bruckert and Parent. A search warrant to seize the interview tape and transcript from lawyer Peter Jacobsen's office, executed on 21 June 2012, was authorized on the basis of McLeod's revelation. A sealed envelope containing the interview was surrendered to police with the promise that it would not be opened until the courts had an opportunity to rule on a claim of researcherparticipant privilege.

As occurred with Ogden in 1994, Bruckert and Parent's university would react by expressing its verbal "support" for the two professor/researchers while

5 John Henry Wigmore, A Treatise on the System of Evidence in Trials at Common Law, Including the Statutes and Judicial Decisions of All Jurisdictions of the United States, England, and Canada (Boston: Little, Brown and Company, 1905); Beverley McLachlin, "Confidential Communications and the Law of Privilege," University of British Columbia Law Review, 11 (1977): 266-84.

6 Ogden was represented by Mr. E. David Crossin, QC.

7 "Inquest of Unknown Female," October 20, 1994. Oral reasons for judgment of the Honourable L. W. Campbell, 91-240-0838, Burnaby, B.C., p 9.

8 Michael Jackson and Marilyn MacCrimmon, Research Confidentiality and Academic Privilege: A Legal Opinion (Burnaby, BC: Simon Fraser University, June 7, 1999). Online at http://www. sfu.ca/ palys/JackMacOpinion.pdf. 
simultaneously abandoning them and their research participants to their own devices in terms of legal representation. In the words of University of Ottawa President Allan Rock,

The University of Ottawa recognizes its role ... in safeguarding entrusted information. However, the University does not consider that its role extends to the payment of legal costs if researchers decide to challenge the seizure of research records in the context of criminal proceedings. ${ }^{9}$

Fortunately, James Turk, then Executive Director of the Canadian Association of University Teachers (CAUT), understood the significance of the case and the need to activate an immediate legal response. Accordingly, CAUT stepped in to ensure the two researchers were adequately represented until the University of Ottawa lived up to its responsibilities expressed in the Tri-Council Policy Statement (TCPS) on ethics in research with human participants. ${ }^{10}$

Justice Sophie Bourque of the Quebec Superior Court framed her decision by first noting that the "general rule" is that "relevant information is presumptively admissible," i.e., in the present context, the court begins with the presumption that the Jimmy interview, which was obtained by bona fide search warrant, is admissible. ${ }^{11}$ From that starting point,

The main question raised by this certiorari application is [thus] whether the Petitioners can exempt themselves from this obligation of disclosure on the basis of a researcher participant confidentiality privilege rooted in the common law in order to protect their confidential, academic research work product. ${ }^{12}$

The case juxtaposes two often competing interests. On the one hand is a need for effective law enforcement to provide justice in specific cases and the protection of the public more generally. On the other hand lies the ability of university researchers to do research that contributes knowledge to our understanding of important and often controversial issues, some of which can only be done with confidential sources.

In the end, Justice Bourque determined the researchers had met the four Wigmore criteria and hence that the search warrant should be quashed and the tape and transcript returned. This being the first case in which a significant Canadian court has ruled on a claim of researcher-participant privilege, a detailed analysis of Justice Bourque's reasoning is important to undertake for several reasons. First, the judgment raises the bar for those involved in law enforcement and its prosecution; it is clear Justice Bourque believed that communications in the

9 "uOttawa criminologists go to court to protect research confidentiality" CAUT/ACPPU Bulletin, 60 no. 1 (January, 2013). Online at http://www.cautbulletin.ca/default.asp?SectionID=0\&Section Name $=\&$ VolID $=354 \&$ VolumeName $=$ No $\% 201 \&$ VolumeStartDate $=$ January $\% 2017, \% 202013 \&$ Edi tionID=38\&EditionName=Vol\%2060\&EditionStartDate=January\%2017,\%202013\&ArticleID=0. Article 5.1 of the TCPS states that, "Institutions shall support their researchers in maintaining promises of confidentiality." The University of Ottawa later was found to be in violation of that article- "support" meant more than offering oral assertions and included providing legal representation-and subsequently reimbursed CAUT $\$ 150,000$, which represented half of CAUT's actual legal costs. See Palys and Lowman, Protecting Research Confidentiality, supra note 2.

12 Ibid, at para 3. 
context of academic research should be treated with respect and that the Crown and/or the police should not expect to be granted a subpoena or search warrant that seeks to access research information gained in confidence simply because they ask for one. Second, within the academic community, an analysis of the decision allows researchers to benefit by seeing how Professors Bruckert and Parent designed their research and how the court interpreted the various design features they incorporated that contributed to, or had the potential to undermine, the judgment. Additionally, research ethics boards can benefit by seeing the role that the TCPS, the University of Ottawa's Research Ethics Board (REB) and the Wigmore criteria played in the court's consideration of the facts so that they might best guide researchers in designing their research to anticipate the court's evidentiary requirements and thereby maximize their likelihood of successfully defending research participant confidentiality if their research were to come under similar scrutiny.

\section{The Wigmore Criteria}

In general, citizens have the obligation to appear in court when summoned and to testify on matters for which they have knowledge or expertise. The exceptions to this rule are known as "privileges." ${ }^{13}$ Some privileges are created in statute, such as the privilege extended to Statistics Canada researchers and their participants via the Statistics Act. The courts also can decide whether recognition of a particular privilege is in the public interest in situations where the privilege is necessary for the "perfect working of a special relation, wherever confidence is a necessary feature of that perfect working." ${ }^{\prime 4}$ The lawyer-client relationship, for example, is protected by a "class" privilege created in common law whereby the courts start with the assumption that any communications between lawyer and client are privileged. It is easy to see why. If charged with a criminal offence or sued by another party, why would you confide in a lawyer if s/he could be called the next day as a witness for the opposing side? In order to be able to defend yourself against criminal charges or engage a civil action, you must be able to confide in your lawyer. And yet, "class" privileges are not absolute; if another party believes that some information should be disclosed, they could petition the court, but the onus would be on them to demonstrate to the court why a recognized privilege should be set aside.

In cases where neither a statute-based nor class privilege exists-as is the case in Canada with the researcher-participant relationship outside of Statistics Canada-one can still claim a privilege for the communications that arose in a particular relationship. However, the onus is on the person claiming the privilege to demonstrate why their communications should be considered privileged in that particular case. One does so, says the Supreme Court, ${ }^{15}$ by showing the communications in that relationship meet the Wigmore criteria. These are:

See Palys and Lowman, Protecting Research Confidentiality, supra note 2.

Wigmore, Trials at Common Law, supra note 5 at 3211.

The original statement was in Slavutych $v$ Baker, [1976] 1 SCR 254. See also McLachlin, supra note 5 . 
1. The communications must originate in a confidence that they will not be disclosed;

2. This element of confidentiality must be essential to the full and satisfactory maintenance of the relation between the parties;

3. The relation must be one which in the opinion of the community ought to be sedulously fostered; and

4. The injury that would inure to the relation by the disclosure of the communications must be greater than the benefit thereby gained for the correct disposal of litigation. $^{16}$

A particularly helpful aspect of the decision is that although the Crown eventually conceded that the Petitioners had satisfied criteria one through three-but not criterion four-the court considered all four criteria in its judgment.

\section{Criterion One: The Communications Must Originate in a Confidence that They Will Not be Disclosed}

Two legal concepts are integral to the first criterion. The first is implicit in the criterion itself, i.e., there must be an expectation of confidentiality shared by both parties in the relationship. In practice this means there must be some clear statement between the parties to the effect that "this interaction is confidential." A significant lesson in this regard arose in $R v$ Gruenke. ${ }^{17}$ Ms. Gruenke had pleaded not guilty to a charge of murdering her former employer, but revealed to her pastor one day that she was actually guilty of the crime. When the Crown sought to have the pastor testify, Ms. Gruenke argued that her discussions with the pastor were subject to priest-penitent privilege and should not be disclosed at trial. But the Supreme Court disagreed, stating that her admissions to the pastor did not take place in a confessional; nor was there any explicit request or statement by either of the parties that their conversation was a confidential one. Accordingly, the Supreme Court rejected the claim on the basis of having failed the Wigmore test on criterion one.

A second important concept involves "waiver of privilege." Even if a conversation is privileged, the individual who owns the privilege (i.e., the client in the lawyer-client relationship; the research participant in the researcher-participant relationship) can waive privilege and thereby release the individual whose duty is to safeguard the privilege (i.e., the lawyer, the researcher) from their obligation. A seminal case in this regard is $M(A) v$ Ryan, which involved a claim for therapistclient privilege. ${ }^{18}$ In that case, $M$ had gone to see a therapist (Dr. Ryan), was sexually assaulted by him, and then went to see a second therapist (Dr. Parfitt) while suing the first. M and Dr. Parfitt discussed the possibility that Dr. Ryan would seek disclosure of Dr. Parfitt's notes. He did indeed attempt to do so, arguing in part that Dr. Parfitt and her client had effectively waived privilege when they discussed the possibility of disclosure. However, the Supreme Court disagreed, stating that

Wigmore, Trials at Common Law, supra note 5 at 3211. Italics in original. 
The communications were made in confidence. The appellant stipulated that they should remain confidential and Dr. Parfitt agreed that she would do everything possible to keep them confidential. The possibility that a court might order them disclosed at some future date over their objections does not change the fact that the communications were made in confidence. ${ }^{19}$

Indeed, as the justices further explained, "If the appellant had privilege in the documents, it could be lost only by waiver, and the appellant's conduct does not support a finding of waiver." ${ }^{20}$

Upon considering Bruckert and Parent's research protocol, Justice Bourque found there was abundant evidence relevant to the first criterion. The original funding proposal that went to the Social Science and Humanities Research Council (SSHRC), the proposal that went to the University of Ottawa REB for ethics review, and the recruitment flyer that went to participants all "made explicit reference to the promise of confidentiality and anonymity attached to the research process" 21 and, more importantly, made the argument for the importance of confidentiality for the participants in this particular study. Confidentiality issues were central during all aspects of the training of interviewers as well, and an explanation of the procedures that would be used to ensure confidentiality-avoiding a paper trail by relying on verbal consent instead of requiring participants to sign a consent form, anonymized transcription, secure data storage-all were part of the recruitment protocol.

The Court also noted that, "There was no limitation to the promise of confidentiality given by the interviewers to the participants." 22 This was important because any limitation to an outright pledge runs the risk of being interpreted as a waiver of privilege. Bruckert and Parent's pledge of confidentiality was unequivocal, and Magnotta did not release them from their pledge. Although Magnotta did acknowledge in his affidavit that he was "Jimmy", he also stated, "I was assured by the people making the interview that it would be private and confidential," and, "I want the interview and notes, if such exist, to remain private and confidential."23

Notwithstanding the above, two facts were highlighted by the Crown as potentially undermining the case for privilege. The first was that, subsequent to the interview, "Jimmy" had initiated contact with the research assistant who had interviewed him, but used his real name instead of his pseudonym when doing so. The Crown suggested this showed Magnotta had no expectation of confidentiality for any of the communications that arose from those exchanges. However, Justice Bourque noted that, as the interviewer, McLeod already knew Jimmy's real name, and that, "Nothing indicates that Jimmy sent those e-mails to a third party or that he authorized McLeod to do so." 24 Accordingly, those interchanges also were considered covered by the researchers' promise of confidentiality.

Ibid. at para 24.

Ibid. at para 14 .

$R v$ Parent, supra note 11 at para 47.

Ibid. at para 53.

$R v$ Parent, supra note 11 at para 64

Ibid. at para 97. 
A second potential problem arose from McLeod's having approached the Montreal police about the existence of the Jimmy interview and its connection to Magnotta. The Crown argued that this showed McLeod did not feel bound by any promise of confidentiality, and if he did not feel bound by one, then the "mutual expectation of confidentiality" required for criterion one is violated, and any claim for privilege should be denied. The Court disagreed with this interpretation, stating that, "McLeod could not unilaterally revoke the confidentiality promise." This is because any privilege that is associated with the researcher-participant relationship actually belongs to the participant, and hence it is only the participant-not a research assistant or even the principal investigator-who can waive it.

The Court concluded the evidence showed there was indeed a shared expectation of confidentiality between Jimmy and the researchers, and in the absence of any waiver of privilege on the part of Magnotta, that the Petitioners clearly met criterion one. The Crown accepted that conclusion.

\section{Criterion Two: Confidentiality Must be Essential to the Full and Satisfactory Maintenance of the Relation Between the Parties}

As Justice Bourque affirmed, "Confidentiality alone does not make a communication privileged from disclosure." 25 Bruckert and Parent next had to show that it would not have been possible to conduct this particular research project were it not for the provision of confidentiality to participants. Once again, the evidence was plentiful.

Perhaps most importantly, Justice Bourque noted that the project would not have been approved had Bruckert and Parent not shown that the confidentiality of participants would be protected because the TCPS, the University of Ottawa REB, and SSHRC (the funding agency) all required it. As this suggests, if confidentiality were not possible, either because a researcher was not prepared to offer it or because circumstances made it impossible to achieve, it is not as if the data would somehow still be there for anyone who might wish to argue for disclosure. Without a solid expectation of confidentiality, the data likely would not exist in the first place.

The decision also recognized how difficult and lengthy a process it can be to earn the trust of a marginalized community. Justice Bourque notes, for example, that the researchers' affidavits revealed it took almost four years for them to achieve their sampling goal of sixty participants, notwithstanding the fact the researchers had been cultivating relationships with the sex worker community for more than a decade. Noting that sex workers are a "vulnerable population" whose work is "clandestine and stigmatized," 26 the Court also accepted evidence from the researchers describing the harms that could befall sex workers if the confidentiality of their responses was not maintained:

a) exposing participants to risk of legal harm, such as Criminal Code charges or seizure of one's children; 
b) exposing participants to risk of personal harm (discrimination, ostracism) by possibly endangering their relationships with family members, neighbours, service providers, employers, landlords, etc.;

c) exposing participants to safety hazard, especially if their names and personal information are disclosed to their clients;

d) exposing participants to financial risk and risk of not being able to continue to work as a sex worker, should their relationships with their clients, which forms the basis of their livelihood, dissolve, as discretion is the very foundation of the participants' work, and participating in interviews risks identifying clients;

e) exposing participants to risk of exclusion from the sex worker community for their failure to uphold the professional code of conduct, as participating in interviews often results in sharing information about other members of the industry; and

f) exposing male escorts to the risk of additional stigmatization based on homophobia. ${ }^{27}$

The evidence of the Petitioners was supplemented by expert evidence from Dr. John Lowman, a distinguished criminologist who has done research in the sex worker community for more than three decades. He, too, spoke of the prospective harms that would be incurred by individuals in the sex worker community if a disclosure were to be ordered. These included the possibility of "being cut off welfare or unemployment insurance benefits, being pursued by Revenue Canada for unpaid taxes, or having their children harassed or bullied by other children at school." ${ }^{28}$

The abundance of evidence led the Court to conclude that, "Wigmore's second criterion is clearly satisfied: Jimmy's interview could not have been conducted without a solemn initial promise of confidentiality and anonymity and the subsequent, continued fulfillment of this promise.". ${ }^{29}$ The Crown also accepted that the Petitioners had met the second criterion.

\title{
Criterion Three: The Relation Must be One that in the Opinion of the Community Ought to be Sedulously Fostered
}

As Justice Bourque explained, "The third criterion is about the relationship itself and not about the content of the impugned communication. The court ought to examine the relationship and determine if it should be deliberately and consciously fostered and protected in the public interest." ${ }^{\prime 3}$ Evidence on this criterion came in part from decisions by the courts, which had shown time and again a respect for the role that academics and academic research play in society and the important place of academic freedom in the production of knowledge. Justice LaForest's view in McKinney v University of Guelph, ${ }^{31}$ in which he notes that academic freedom is

\author{
Ibid. at para 103 . \\ Ibid. at para 104. \\ Ibid. at para 112 . \\ Ibid. at para 114. \\ McKinney v University of Guelph, [1990] 3 SCR 229.
}


necessary to allow "free and fearless search for knowledge and the propagation of ideas" and is "essential to our continuance as a lively democracy," was cited approvingly. ${ }^{32}$ Further on this point, the decision continued,

The Supreme Court of Canada has been very cautious over the years in intervening in university affairs, recognizing the importance of academic freedom in safeguarding the role of universities as self-governing centers of research, teaching and learning.

In other words, academic freedom and the importance of institutions of higher learning and academic research are key components of a democracy that values freedom of thought and expression. ${ }^{33}$

One important distinguishing feature of the academic research community is that, "academic researchers are subject to great institutional accountability especially towards REBs which approve and monitor all research at universities where human subjects are involved." ${ }^{34}$ Sections of the TCPS that govern this review and approval process were quoted at length in the decision-eleven paragraphs spread over two pages - that speak to the importance of the researcher-participant relationship to academic research and how "[i]t puts a heavy ethical onus on academics to protect to the best of their ability their relationships with participants, the participants' anonymity and privacy, and the confidentiality of the information gathered."35

Another illustration of the importance of research to society "is found in the absolute statutory protection granted to Statistics Canada researchers, who may not be compelled to testify or produce information in any proceeding." ${ }^{36}$ Noting also some of the similarity between academic researchers and journalists, Justice Bourque went on to state, "The Supreme Court of Canada recognized in National Post that 'unless the media can offer anonymity in situations where sources would otherwise dry up, freedom of expression in debate on matters of public interest would be badly compromised." 37

The Court was clearly convinced how useful and informative academic research can be, and the importance of confidentiality to much of that work. As Justice Bourque concluded,

[T] he Court agrees with the proposition that much academic research, especially that which explores the areas outlined above, provides useful information on certain aspects of the human condition that are normally kept silent. This information is essential to understand and improve the social condition of vulnerable and marginalized communities....

Confidentiality promise has the potential to not only encourage vulnerable and marginalized people to come forward and be interviewed, but to maintain the quality, accuracy, and scientific value of the information collected by researchers. ${ }^{38}$

$R v$ Parent, supra note 11 at para 121.

Ibid. at paras 122-3.

Ibid. at para 119.

Ibid. at para 125 .

Ibid. at para 127.

Ibid. at para 128 .

Ibid. at paras 130, 138. 
Justice Bourque concluded that the Petitioners had thus satisfied the third criterion of the Wigmore test, and the Crown agreed. ${ }^{39}$

\section{Criterion Four: The Injury that Would Inure to the Relation by the Disclosure of the Communications Must be Greater than the Benefit Thereby Gained for the Correct Disposal of Litigation}

Any well-designed research project involving sensitive information where confidentiality is crucial to the acquisition of valid and reliable data and to the protection of research participants from harm should be able to pass the first three Wigmore criteria. It is the fourth criterion where rubber hits the road and the Court will weigh the competing interests to determine some resolution that takes both sets of compelling social objectives into consideration. Justice Binnie articulated the dilemma in R. $v$ National Post:

The public has an interest in effective law enforcement. The public also has an interest in being informed about matters of importance that may only see the light of day through the cooperation of sources who will not speak except on condition of confidentiality. [...] It is important, therefore, to strike the proper balance between two public interests-the public interest in the suppression of crime and the public interest in the free flow of accurate and pertinent information. Civil society requires the former. Democratic institutions and social justice will suffer without the latter. ${ }^{40}$

This weighing is ground in the unique circumstances of each case, with the exact circumstances of this exercise largely unforeseeable at the time the research is being designed and executed. ${ }^{41}$ Because of the general presumption that all citizens are expected to give evidence when called as witnesses, in case-by-case claims to privilege the onus is on the petitioners "to show that the public interest in protecting the Jimmy-researchers relationship outweighs the public interest in investigating and prosecuting the alleged crime." 42 This calls for a review of both sides of the ledger-the need for the information by the court in bringing some just resolution to the civil or criminal matter before it versus the prospective impact that a disclosure would have on the socially valued researcher-participant relationship.

\section{The Interest in Investigation and Enforcement}

Clearly, there is a strong public interest in the investigation and prosecution of crime, and the grotesque murder of Lin Jun called particularly strongly for attention to this interest. And yet, the interest in law enforcement is not absolute,

\footnotetext{
39 Ibid. at paras $143-4$.

40 Justice Binnie writing for the majority in $R v$ National Post, 2010 SCC 16, [2010] 1 SCR 477 at para 28, quoted by Justice Bourque in $R v$ Parent, supra note 11 at para 91.

41 For example, it is unlikely that Professors Bruckert and Parent anticipated that one of the sex workers they were interviewing in 2007 would be charged with a grisly murder in 2012 . On the other hand, when Russel Ogden was undertaking his MA research on assisted suicide, he correctly speculated in his proposal that if any legal authority were to become interested in his work, it was likely to be the Coroner.

$42 \quad R v$ Parent, supra note 11 at para 148.
} 
however heinous the crime. As Justice Bourque explained, "the existence of a crime is not sufficient to annihilate a case-by-case privilege claim," ${ }^{, 3}$ and even in a case such as this, "fishing expeditions are not appropriate where there is a compelling privacy interest at stake." ${ }^{44}$ The first questions the Court needs to ask are whether the information sought is specific and well-defined, and if so, whether it is available through any other means: "One must exhaust possibilities of obtaining the information before requiring a researcher to break his or her promise of confidentiality. ${ }^{\prime 5}$ In that regard, the court took note the 2007 interview was conducted a full five years before the crime, and four years before Lin Jun even entered the country to pursue his education. This made it highly unlikely that the interview would contain any evidence that would speak to Magnotta's connection to the victim, or to his guilt or innocence for a crime committed in 2012. Added to that was what appeared to be plentiful evidence not subject to a claim of privilege that could connect Magnotta to the crime, e.g., a video of the slaying, surveillance video showing Magnotta carrying suitcases later determined to contain body parts, and physical evidence found in Magnotta's apartment.

An even more fundamental question is relevance. Although the Crown would argue that both the interview and the murder had a sexual dimension to them, and the research assistant's decision to inform Montreal police about the existence of the interview might suggest that McLeod believed the interview had some relevance to the case, the Court dismissed these justifications. No evidence was presented that the murder occurred in the context of Magnotta's work as an escort, and the possible "insinuation that a sex worker is the type of person more likely to commit murder ... cannot convince the Court." ${ }^{\text {"46 }}$ Similarly, McLeod was never called to testify or to produce an affidavit, such that any inference as to his motivation in contacting police was "pure speculation and it cannot serve as a ground to determine if transcripts are of probative value for the upcoming murder trial., ${ }^{37}$

The Jimmy interview thus was unlikely to be useful in determining whether Magnotta actually committed the crime. However, the Crown continued to pursue the interview in anticipation of Magnotta's attorneys introducing an NCR defence-that he was not criminally responsible for the crime by reason of his mental illness-in the belief the interview might shed light on Magnotta's mental state or competence at a time when his behaviour was not under court scrutiny.

Bruckert and Parent's attorneys anticipated this consideration by introducing expert evidence from Dr. Scott Woodside, a psychiatrist. He had practiced in the area of forensic psychiatry for sixteen years, had been a member for three years of the Ontario Review Board that reviews the status of every person who has been found not criminally responsible or unfit to stand trial, and had conducted "500 to 600 assessments of individuals to determine whether or not they would have a NCR defence due to a mental disorder pursuant to s. 16 of the Criminal Code." ${ }^{\text {4 }}$

Ibid. at para 150 .

Ibid. at para 172 .

Ibid. at para 152 .

Ibid. at para 157.

Ibid. at para 158 .

Ibid. at para 75. 
In Dr. Woodside's opinion, the Jimmy interview might conceivably have some "remote relevance" to a determination of whether Magnotta was showing any indication of a mental disorder five years previous, but was completely unlikely to be helpful in determining the other criteria that are involved in an NCR assessment that address the relevance of the accused's mental illness at the time of the offence. $^{49}$

\section{The Public Interest in Sedulously Fostering Research Confidentiality}

While there was little to recommend the interview for its utility to the legal case against Magnotta, the pan on the other side of the balance was brim full. Parent and Bruckert both had submitted affidavits in which they outlined the difficulties of gaining the trust of individuals in the sex work community and the crucial role that trust played in people's willingness to participate. This view was reaffirmed in expert testimony by Professor Lowman.

In contrast, the Crown argued that Parent and Bruckert had failed to demonstrate that "the disclosure of the confidential interview transcripts could have a real negative impact on the Petitioners' research projects." 50 But the Court disagreed, stating,

The evidence shows that Dr. Bruckert has been advised by one of her contacts in the sex worker community that she is regarded by this contact as having failed in her duty to uphold the promise of confidentiality in this case. Dr. Bruckert has also been advised by several of her contacts in the sex worker community that confidentiality is critical to their decision to participate in a research project: the majority of her contacts would not participate in the absence of a binding promise of confidentiality. There is a non-negligible risk that if Petitioners are forced to violate their promise of confidentiality in this case, their ability to continue to conduct research into sex work would be harmed....

The evidence supports the conclusion that both Petitioners['] ability to undertake a similar research project in the future would be jeopardized if the promise of confidentiality is not upheld in this application. ${ }^{51}$

It is noteworthy that the Court's consideration of this case came within a year of the Supreme Court's decision in Canada (Attorney General) $v$ Bedford, ${ }^{52}$ a challenge brought under the Canadian Charter of Rights and Freedoms ${ }^{53}$ where the laws surrounding the sex industry were scrutinized. Expert testimony from sex researchers, including appellant Bruckert and expert witness Lowman, based on their empirical work in studies such as the one that Magnotta had participated in, played a crucial role in the Court's determinations regarding the impact of the law on prostitution. As Justice Bourque noted,

Ibid. at paras $165-7$.

Ibid. at para 202.

Ibid. at paras 203-5.

Canada (Attorney General) v Bedford, 2013 SCC 72, [2013] 3 SCR 1101.

Canadian Charter of Rights and Freedoms, Part I of the Constitution Act, 1982, being Schedule B to the Canada Act 1982 (UK), 1982, c 11 [hereafter Charter]. 
The Bedford case has taught us that the issues raised by such a constitutional challenge could be decided primarily because of a rich evidentiary record, comprising data derived from academic research on various prostitution aspects (safety, poverty, housing, morality, and economics), criminal law, ethics and public health. ${ }^{54}$

It was a recent and relevant example of the value of empirical research in aiding the Courts in their decision-making on socially important and controversial topics, and thus a highly germane illustration of the sorts of information that could be lost if the courts were to deny a claim of privilege for the researcher-participant relationship and thereby declare open season on research participants.

The balancing of interests in each case also calls for consideration of how the various interests reflect Charter values, and the current case is no exception. The question of a researcher-participant privilege speaks directly to rights of privacy recognized by the Supreme Court as residing in section 8 of the Charter. Justice Bourque cited approvingly the Supreme Court's decision in $R v$ Mills $^{55}$ to the effect that,

This interest in being left alone by the state includes the ability to control the dissemination of confidential information.... These privacy concerns are at their strongest where aspects of one's individual identity are at stake, such as in the context of information "about one's lifestyle, intimate relations or political or religious opinions."

The decision also notes that it is exactly these issues-information about sexual preferences, his work history, relations with clients, reconciliation of his personal and work life, experiences with discrimination and stigma-that the "wide-ranging" interview addressed, and hence "for which [Magnotta] has a reasonable expectation of privacy." 57

\section{A Fly in the Ointment?}

The facts above appear highly imbalanced in favour of recognition of privilege in this case. Justice Bourque herself noted,

The fact that more relevant contemporary material in regards to his mental state do exist, that Magnotta has a reasonable expectation of privacy, and that Dr. Woodside's opinion that the 2007 material is likely to be of minimal assistance to a NCR assessment militate in favor of recognizing a privilege at this stage. ${ }^{58}$

Was it then superfluous for Justice Bourque to take the added step of actually opening the envelope to read the interview transcript? The matter was within her discretion. The Supreme Court in $M(A) v$ Ryan, noted that while

"a judge does not necessarily err by proceeding on affidavit material indicating the nature of the information and its expected relevance without inspecting each document individually," the minute examination of a

$R v$ Parent, supra note 11 at para 198.

$R v$ Mills, [1999] 3 SCR 668.

Cited in $R v$ Parent, supra note 11 at para 174.

Ibid. at para 176 .

Ibid. at para 177. 
document must be undertaken "where necessary to the proper determination of the claim for privilege." 59

In sum, while the Court could have relied on affidavit evidence without actually opening the envelope to examine the interview transcript, opening the envelope was also permissible if Justice Bourque believed it was necessary to make her assessment regarding privilege. She addresses this issue by saying only, "[T] he possibility remains that the information derived from the Confidential Interview could be of use to an NCR assessment. This possibility cannot be excluded, even in the light of Dr. Woodside's evidence." ${ }^{60}$ Justice Bourque then elaborates on her choice by noting that the interview guide McLeod presumably followed contained broad open-ended questions that might have seen Magnotta respond with information that could be relevant to an NCR defence. She also quotes the following passage from $M(A)$ v. Ryan:

It must be conceded that a test for privilege which permits the court to occasionally reject an otherwise well-founded claim for privilege in the interests of getting at the truth may not offer patients a guarantee that communications with their psychiatrists will never be disclosed. On the other hand, the assurance that disclosure will be ordered only where clearly necessary and then only to the extent necessary is likely to permit many to avail themselves of psychiatric counselling when certain disclosure might make them hesitate or decline. ${ }^{61}$

The quote is part of a discussion regarding the possibility of ordering a partial disclosure if parts of the interview were relevant to a prospective NCR defence. Presumably the purpose of quoting that passage is because Justice Bourque believes the same will be true of research participants, i.e., that people such as Magnotta will still participate in research as long as they know the court will disclose only the minimal information necessary to resolve the legal issue at hand.

The analogy is problematic in several respects. First, the statement seems inconsistent with the nature of privilege. The quoted passage asserts that prospective patients (or, by analogy, prospective research participants) who are concerned about their confidentiality will seek therapeutic help (or participate in research) even though they know that some of what they reveal may well be disclosed if it is needed for some legitimate legal purpose. However, the second Wigmore criterion states that confidentiality must be essential to the relationship. If prospective patients (or prospective research participants) would go to therapists (participate in research) despite knowing that some of the secrets they are sharing might be disclosed, would that not constitute a failure under criterion two? That is exactly the argument Wigmore himself made when rejecting the idea of a physician-patient privilege; other than for embarrassing or stigmatizing conditions such as sexually transmitted diseases or criminal abortion, said Wigmore, who would stop going to see a physician if they needed medical assistance regardless of the possibility of disclosure? ${ }^{62}$

$M(A) v$ Ryan, supra note 18 at para 39. Quoted by Justice Bourque at para 182.

Ibid. at para 178 .

$M(A) v$ Ryan, Ibid. at paras 35 and 37. Quoted by Justice Bourque at para 184.

Wigmore, Trials at Common Law, supra 5 at 3350-1. 
Second, the analogy assumes that individuals seeking therapy and prospective research participants who engage in sex work and other kinds of criminal behaviour understand the justice system in similar ways. In contrast, we find that individuals who belong to vulnerable, stigmatized and marginalized communities and/or who engage in criminal lifestyles are less likely to see the criminal justice system as a benevolent benefactor looking out for their interests, and more likely to see law and the justice system as the source of their stigmatization. In that sense, the lessons to be drawn from the Supreme Court are less like the circumstances in $M(A) v$. Ryan, and more like the situation in Smith $v$ Jones. In that case, a psychiatrist (Dr. Smith) who had examined an offender (Mr. Jones) at the behest of Jones's lawyer petitioned the court to disclose his finding that Jones would represent a significant danger to the life and limb of sex workers working in a particular area in Vancouver if he were to be let back into the community without treatment. Although the Supreme Court determined that lawyer-client privilege could be set aside and a disclosure permissible given the specific circumstances of that case, Justice Major expressed caution in a partial dissent regarding the impact of any disclosure on those who might otherwise seek treatment for their violent propensities:

As appealing as it may be to ensure that Mr. Jones does not slip back into the community without treatment for his condition, completely lifting the privilege and allowing his confidential communications to his legal advisor to be used against him in the most detrimental ways will not promote public safety, only silence. For this doubtful gain, the Court will have imposed a veil of secrecy between criminal accused and their counsel which the solicitorclient privilege was developed to prevent. Sanctioning a breach of privilege too hastily erodes the workings of the system of law in exchange for an illusory gain in public safety. ${ }^{63}$

Third, as Palys and Lowman have argued, ${ }^{64}$ the researcher-participant relationship is unlike other confidential relationships in many respects, one of which is the typically voluntary and altruistic nature of participants' involvement. In the lawyerclient relationship, clients disclose information in order to obtain advice or build a defence; in the therapist-client relationship, patients share information in the hope of being counselled toward a better quality of life; in the priest-penitent relationship, the penitent confesses his/her sins seeking forgiveness and absolution. In every case, the person invoking the privilege has something to gain from the interaction, such that any prospect of disclosure can be weighed against the gains to be had by involvement in the relationship. But participants in research typically have nothing to gain by participating in research other than some general sense of possibly contributing to knowledge or perhaps influencing the development of law or policy at some future time. The comparison is even more uneven when the population under consideration is marginalized, stigmatized, vulnerable, and engaged in activities that are considered illegal or deviant, as was the case here. In our experience, such individuals often have a mistrust of, or at best a fragile trust in, the justice

63 Smith $v$ Jones, [1999] 1 SCR 455 at para 23.

64 Palys and Lowman, Protecting Research Confidentiality, supra note 2. 
system that is well founded in their interactions, particularly with police. Even a remote prospect of disclosure thus swings a rational calculus to non-participation.

\section{Discussion and Conclusions}

The court's decision in $R v$ Parent encourages both optimism and caution. The optimism arises from the court's recognition of a qualified research participant privilege in a challenging case where, because of the heinous nature of the crime and distinct lack of sympathy generated by its perpetrator, the knee jerk reaction might well be to say that offenders such as Magnotta deserve no protection. ${ }^{65}$ Although the Quebec Superior Court is not the Supreme Court, it establishes a high-ranking precedent for Quebec that ensures it will at least be read and addressed by the judiciary in other provinces. As such, it represents the first significant look the research community has at the sorts of issues that have arisen and may continue to crop up in future cases, where a third party seeks the confidential identity or responses of a research participant. The caution arises because it is only the first such case to be considered in a superior court, and because it introduces as many questions as it resolves. Accordingly, it is useful to review what we can learn from $R v$ Parent to ensure that academic researchers are as ready as possible to protect their research participants when and if the next case arises.

A first lesson is that researchers' institutions must be ready to provide legal support to their researchers in order to fulfill their ethical obligations to protect research participants and contractual obligations to the granting agencies to abide by the TCPS. We all should be thankful that CAUT stepped in to ensure that Professors Bruckert and Parent were adequately represented; the situation could have been a disaster had the two researchers been left with no more than University of Ottawa President Rock's vacant platitudes of support. A formal complaint against the institution for violating its memorandum of understanding with the granting councils ${ }^{66}$ resulted both in a rebuke of the University's failure to provide legal support and an admonition to research institutions across the country to have policies in place to ensure a proper and speedy legal response when and if the next researcher is subpoenaed. ${ }^{67}$ It is unclear at this point how many institutions have done so.

Given that a defence is undertaken, $R v$ Parent reaffirms the Wigmore criteria are the appropriate vehicle for the court to adjudicate claims to privilege for the researcher-participant relationship. At least three formal legal opinions have stated as much. ${ }^{68}$ The logical consequence to this state of affairs is for researchers investigating controversial issues where confidentiality is essential to gathering reliable

65 This has been the most common initial response in talks the first author has given on this case.

66 https://www.cautbulletin.ca/en_article.asp?ArticleID=3674

67 See http://www.pre.ethics.gc.ca/eng/policy-politique/interpretations/privacy-privee/. The complaint and its resolution are also discussed in Palys and Lowman, Protecting Research Confidentiality, supra 2.

68

Jackson and MacCrimmon, Research Confidentiality and Academic Privilege, supra note 8; Paul Jones "Legal Opinion on Issues of Privilege." Reproduced as Appendix A in John Lowman and Ted Palys, Going the Distance: Lessons for Researchers from Jurisprudence on Privilege (Burnaby, BC: Simon Fraser University, 1999) at 52-58. http://www.sfu.ca/ palys/Distance.pdf; D. Lovett, Legal opinion for Research Ethics Board. Legal opinion commissioned by the SFU Research Ethics Board (2002). 
and valid information to design their research so that it anticipates the requirements of the Wigmore criteria. ${ }^{69}$ Although some matters, such as the exact legal issues that will arise in the case in which the claim for privilege is made, are beyond our control, doing our due diligence by anticipating those elements of the Wigmore criteria for which we can provide positive evidence and avoiding flaws that could be our undoing gives us our best shot at having a researcher-participant privilege recognized, and for the contours of that qualified privilege to be as broad and favourable to research participants as possible.

The Parent decision also shows the high value courts place on the research enterprise and the role of academic freedom in it. An important consequence is that $R v$ Parent puts legal authorities on notice that "fishing expeditions" will not be countenanced; that non-privileged alternative sources of information should be secured and shown to be inadequate before potentially privileged communications are sought; and that the information sought must be demonstrably relevant to the legal issue at hand.

The decision also shows that involvement in criminal activity per se does not vitiate a claim of privilege, as shown in this instance of a particularly heinous crime. Indeed, one important element of this case is that it defies the simplistic characterization of the choice as law enforcement versus the academic freedom of researchers. Instead, this case arose in a situation where the intent of the research was to generate knowledge that would contribute to more informed policy and better law. Protecting research confidentiality thus allows the courts to safeguard academic freedom and serve law enforcement by encouraging research that informs both the courts and legislators, as the Bedford case illustrated.

In terms of procedures, the decision affirms that, as the first criterion demands, any research where a potential claim of privilege might be made must begin with a clear mutual expectation of confidentiality that avoids creating a waiver of privilege. The decision also makes clear that researchers should walk their talk, i.e., if research confidentiality is important, then their behaviour should be consistent with that importance in every respect. The decision is especially useful in showing researchers in a very tangible way the level of detail to which their procedures and practices will be scrutinized. In the case of $R v$ Parent, the evidence included their original ethics proposal to the REB, their funding proposal to SSHRC, all training documents, recruitment brochures, the oral consent process, interview schedules, transcription processes, data storage practices, and their adherence to policies and procedures of the university, the granting agency, the ethics Secretariat, and their discipline. In every case the message was that confidentiality was important, and the behaviour of everyone who was a principal researcher in the project reaffirmed it.

The decision also helped identify weaknesses in the current case that warrant consideration. Certainly major concern must be registered regarding research assistant Adam McLeod's decision to come forward and talk to police without checking with his former employers. This was ill advised, contrary to his training, and could

69 Ted Palys and John Lowman. "Ethical and Legal Strategies for Protecting Confidential Research Information" Canadian Journal of Law and Society 15 no. 1 (2000); Palys \& Lowman, Protecting Research Confidentiality, supra note 2. 
have been the fact that tipped the balance in favour of disclosure if the balancing of interests in relation to criterion four had been a closer call. If anonymity of participation is promised, then members of the research team clearly should not be telling police who participated in the research. One lesson learned here is that any case-by-case claim for privilege will only be as good as its weakest link. ${ }^{70} \mathrm{Had}$ McLeod not come forward-and it is important to note that he had no legal reason to do so-it is doubtful this case ever would have happened.

The experience also raises questions about the way we employ pseudonyms in our research. Their putative purpose is to protect participant identity, but we note it has become an increasingly common practice for researchers to allow research participants to choose their own pseudonym, as was the case here. In a retrospective analysis of her experience, ${ }^{71}$ Professor Bruckert suggests a preferred strategy would be for the researcher to supply one, such that the link between a specific person and a specific interview would be known only to the principal investigator in any project. One could even make the destruction of any list connecting the two at the completion of the research part of the long-term plan for ensuring confidentiality. If the interview transcripts were properly anonymized, then the interview would be protected by being simply one in a sea of anonymity - protection through obfuscation - and McLeod's decision to approach police would have had no effect.

Implementing that precaution also would have placated concern regarding the email communication between Jimmy and McLeod that occurred after the study, where Magnotta used his real name. The Crown argued this exchange showed that confidentiality was not important to Magnotta. While the court dismissed that conclusion, noting there was no indication the information Magnotta communicated to McLeod in an email was communicated to others, the implicit message is that if there had been any indication that people who were not members of the research team would hear about Magnotta's (or anyone else's) participation, then it might well constitute a waiver of privilege by showing that confidentiality and anonymity were not as important as originally had been thought. And yet, this only became an issue because Magnotta knew his pseudonym; breaking that connection would have made Magnotta just another research participant asking a question or making a comment about his experience.

Notwithstanding the clear win for researchers and research participants that the $R v$ Parent decision represents, the above-noted flaws in an otherwise welldesigned and executed study remind us to be cautious going forward. A key element of this decision was Justice Bourque's finding of the minimal (if any) relevance of the content of the Jimmy interview to the case at hand, noting that the "probative value" of the interview between Jimmy and the researcher was "at best, minimal and marginal both theoretically and factually." ${ }^{32}$ We can only speculate on the possible impact that variations in case facts might have had on this case-e.g., if Justice Bourque had found the content of the interview to be potentially valuable

70 Christine Bruckert, "Wrong case, right decision: Lessons learned at the University of Ottawa" (paper presented at the School of Criminology, Simon Fraser University, 4 November 2015).

71 Ibid.

72 Ibid. at para 211. 
in assessing Magnotta's mental status in light of a potential NCR defence, or if the interview had occurred around the time of the murder instead of five years before, or if other evidence suggesting Magnotta's involvement in the murder was less compelling and the determination of his guilt or innocence more contentious. As this suggests, notwithstanding how well we design our research, the legal facts and issues surrounding guilt/innocence that will come into play when the costs of disclosure to the researcher-participant relationship are weighed against the needs of the court for that information are for the most part beyond our control.

This in turn raises the question of how broadly the courts will construe "the relationship" under examination, and reveals an interesting dilemma the fourth criterion creates. The essence of the Wigmore test is to allow a case-by-case determination of whether privilege should attach in a specific fact circumstance, or even whether it should attach to certain documents or portions of documents arising in a specific fact circumstance. The objective is not to create new classes of privilege, though in theory that is a possibility, but the third criterion encourages the court to consider the social value attached to the relationship, which pulls us away from intrinsic elements of this case to consider its instrumental implications for the researcher-participant relationship more generally.

Justice Bourque at times evinces these same competing pulls. At times she takes a very localized, fact-specific look at whether the fourth criterion is metreferring specifically to the Jimmy-researchers relationship ${ }^{73}$ - while at other times she considers the balancing in more general terms, noting the importance of the researcher-participant relationship in research involving sex worker populations, or even more broadly defined, "marginalized" and "vulnerable" populations. ${ }^{74}$ This reveals both the strength and the difficulty of the case-by-case approach. Taking a narrow, fact-specific approach has the advantage of focussing the arguments on the issues at hand, which allows recognition of privilege in those instances that especially call for it, but intentionally ignores the broader implications certain decisions may have.

In contrast, placing this case in the context of broader considerations of research with marginalized populations might be taken as a back-door argument for the development of a class privilege, which would run counter to the Supreme Court's recent call to avoid the creation of new class privileges. As the Court opined in National Post, "It is likely that in future such 'class' privileges will be created, if at all, only by legislative action." And yet even in that decision, the Supreme Court evinces the same tensions, speaking at times very clearly about the specific arguments that arose in that case, while at other times waxing more broadly in their consideration of the importance of source confidentiality for the media and the important social role journalists play.

Overall, researchers should rejoice at the decision in $R v$ Parent, while recognizing that this is only the beginning of what potentially may be a very long process not only of reaffirming the existence of the qualified privilege, but more importantly

$R v$ National Post, supra note 40 at para 91. 
of outlining its contours as research confidentiality is pitted against other interests in other criminal cases as well as in the civil sphere. Those "other interests" are in some cases anticipatable and in others not, but the job of researchers, participants, REBs, and university administrations is to ensure the first three criteria are solidly met whenever they are gathering sensitive information that could harm participants if disclosed. Because research is important, not only to university professors but also to the Canadian public and the courts, we share the optimism of legal scholars Jackson and MacCrimmon ${ }^{76}$ that, as long as we design our research to anticipate and address the courts' evidentiary requirements in relation to the Wigmore criteria, it is only in the rarest of circumstances that maintaining the trust and confidence of research participants will be the lesser interest.

At the same time, limitations to the Supreme Court's considerations of privilege and apparent reservations about recognizing new class privileges make us wonder whether, over the longer term, our national conversation about these issues should include the possibility of creating a statute-based research participant privilege. There are various ways these might be accomplished: Statistics Canada's "deemed employee" initiative might be expanded to bring more academic researchers and a broader array of data under the sway of the Statistics Act; ${ }^{77}$ or the Canada Evidence $\mathrm{Act}^{78}$ could be amended; or mechanisms along the lines of the Certificates of Confidentiality ${ }^{79}$ or Privacy Certificates ${ }^{80}$ that exist in the United States for certain types of health and criminological research could be developed. The desirability of such protections, and the relative merits and limitations of different ways of achieving them, require a conversation we encourage Canada's research community to consider. ${ }^{81}$

Ted Palys

School of Criminology

Simon Fraser University

palys@sfu.ca

David MacAlister

School of Criminology

Simon Fraser University

dmacalis@sfu.ca

Jackson and MacCrimmon, Research Confidentiality and Academic Privilege, supra note 8.

See http://www.statcan.gc.ca/eng/rdc/index

http://laws-lois.justice.gc.ca/eng/acts/C-5/

https://humansubjects.nih.gov/coc/index

http://www.nij.gov/funding/humansubjects/Pages/privacy-certificate-guidance.aspx

81 See Palys and Lowman, Protecting Research Confidentiality, supra note 2, for a preliminary discussion of these possibilities. 